https://doi.org/10.22364/htqe.2019.02

\title{
RELATIONAL-SELF-OF-VIRTUE: CLASSICAL, MODERN AND CHRISTIAN PERSPECTIVES IN MORAL EDUCATION
}

\author{
Manuel Joaquín Fernández González \\ University of Latvia, Latvia
}

\begin{abstract}
The multiple ethical issues arising at school age in the digital era cannot be addressed effectively through a fragmented moral education which focusses successively on different virtues. This paper introduces the concept of relational-self-of-virtue: the personal deep disposition to virtue growth in communities of virtue. Based upon a realist Aristotelian understanding of human beings, the concept builds on the theory of the self-of-virtue: the fundamental disposition to grow in virtue. In this paper, based on Polo's anthropology and on 'inter-processual self' theory and practice, this concept is expanded for embracing classical, modern and Christian perspectives in character education. This expanded concept enlarges the theoretical foundations of an educational model for developing youngsters' relational-self-of-virtue, which would contribute to avoid fragmentary moral education and to enhance its effectiveness and sustainability.
\end{abstract}

Keywords: inter-processual self, moral education, relational-self-of-virtue, virtue ethics.

\section{Introduction}

Moral character education is a topical trend in the educational discourse (Carr, 2018; Kristjánsson, 2016; Peters, 2015; Walker, Roberts \& Kristjánsson, 2015). The Jubilee Centre for Character and Virtues (University of Birmingham) defines character as "a set of personal traits or dispositions that produce specific moral emotions, inform motivation and guide conduct. Character education includes all explicit and implicit educational activities that help young people develop positive personal strengths called virtues" (Jubilee Centre, 2017, 2). 
The "character education's profoundest problem" (Kristjánsson, 2015,60 ) is the variety of virtues and the multifaceted nature of virtue: "Evaluating character is currently one of the biggest challenges facing researchers working in the field, partly because 'character' and 'virtues' are such complex constructs" (Harrison, Arthur, n.d., 19). Moreover, the multiplicity and rapidity of the ethical issues that arise at school age in our digital era cannot anymore be addressed effectively through an atomized, fragmented virtue education which would focus on developing different virtues and virtue components successively.

This problem has been addressed from different angles. Some academics and practitioners of character education advocate for focussing on concrete virtues considered to be particularly important, such as gratitude (Emmons, 2009; Morgan, Gulliford, 2017) or resilience (Whitehead, \& Whitehead, 2015). A recent example of this approach is the consultation "Character and Resilience: A call for evidence"1, initiated by the Secretary of State for Education of U.K., who defined character in resilience terms: being able to stick with the task in hand and to bounce back from setbacks. However, reducing moral education to one or some virtues does not seem to be compatible with the unity of virtue and the interconnection of virtues (McCabe, 2016).

Recently, serious efforts for finding deeper alternative approaches to holistic character and virtue education were done in at least two directions. One of them explores the central role of moral identity for understanding moral functioning. This trend is particularly strong in the USA, as illustrated by two recent projects leaded by University of Oklahoma and Marquette University: "The Self, Motivation \& Virtue Project"2 (2015-2018), which provided research grants for interdisciplinary research on the moral self and produced an online "Moral Self Archive" and a "Moral Self Network"; and the project "The Self, Virtue \& Public Life"3 (2018-2021), which supports new research on topics related to the self, virtue and public life, digging deeper into the factors that contribute to supporting or undermining virtue in public life. These projects have the merit of highlighting the social dimension of character education and of recognizing the importance of moral identity, but they are positioned more or less strongly in an antirealist philosophical paradigm which is hardly reconcilable with Aristotelian moral objectivism and philosophical realism.

\footnotetext{
${ }^{1}$ https://consult.education.gov.uk/character-citizenship-cadets-team/character-andresilience-a-call-for-evidence/consultation/subpage.2019-05-22.2980308523/

2 http://smvproject.com/

${ }^{3}$ https://selfvirtueandpubliclife.com/
} 
Another novel research direction takes phronesis (practical wisdom) as the integrating element (Darnell, Gulliford et al., 2019) that would avoid a fragmented character education. This approach goes beyond single-component solutions (e.g., moral reasoning, moral identity or moral emotions alone), and defines phronesis as the combination of four components: constitutive (moral perception), adjudicative (identifying conflicting virtues), emotional (moral emotions), and 'blueprint', related to moral ideals and moral identity (Darnell, Gulliford et el., 2019). Certainly, phronesis is commonly viewed as "the point of articulation between virtue stability and dynamicity: Thanks to phronesis, a virtuous character maintains the 'unity of virtue' in new, unforeseen situations" (Fernández González, 2019, 14). However, it could be argued that this model does not address clearly the relative weight of each component and the crucial role of freedom in the configuration of the deep moral disposition of the person.

Recently a new approach to holistic moral education was put forward, which, from a realistic Aristotelian perspective, recognizes both the role of the moral self and human freedom in moral life, and the unity of virtue. It is the theory of the self-of-virtue (Fernández González, 2019), which will be summarized and critically analysed in the next section.

\section{Theoretical background: Re-questioning the self-of-virtue}

Within a realist Aristotelian paradigm, the concept of self-of-virtue captures the relevance of the person's fundamental and freely developed disposition to grow in virtue for moral development (Fernández González, 2019, 11). This disposition "is different from the 'states of character' of the different virtues. It is the person's deep disposition to acquire and develop all these habitus or virtues, and it could be called a meta-disposition: the fundamental disposition to acquire virtuous dispositions" (p. 15).

This theory, following Polo's (1999; 2007) anthropology, conceives virtue as an 'integrative' reality. This means that the acquisition of virtue is possible, optional, and should be intentionally provoked, and therefore it is not automatic, nor compulsory, nor necessary (it is contingent) (Orón, 2015, 116): virtue growth (the acquisition of moral habits) is a possibility that can be freely actualized by a personal decision, and is attainable through personal effort, more concretely, through phronesis-guided action. The theory of self-of-virtue sees also virtue as an 'open free system' (Polo, 2007), in which the different virtues are systemically interconnected and can develop organically without restriction.

The concept of self-of virtue represented a conceptual and practical step-forward in the field of character education: conceptually, it integrates, at the level of the deep dispositions of the person, the multiple components 
of virtue, namely, rationally grounded moral emotions, a personal free commitment to virtue growth, virtuous behaviour guided by phronesis, and reflective self-knowledge. This concept captures both the dispositional stability of the virtue and the person's 'self' agency and freedom in virtue growth. The concept of self-of-virtue has also relevant practical educational consequences, because, by focussing on the person's deep moral disposition to virtue growth, from where all virtues spring, gives youngsters' a sense of purpose in life (the motivation to become a good person), instead of educating particular character strengths or virtues in a random and fragmentary way (Fernández González, 2019, 25-26).

However, in its current state, the theory of the self-of-virtue presents also some shortfalls. Two main concerns appeared in academic discussions around this concept: an anthropological one and a societal one.

Anthropologically, the self-of-virtue theory does not cover sufficiently the relational dimension of human beings. This critique can be better understood on the basis of Polo's anthropology (Polo \& Corazón, 2005). Polo understands human beings as possessing three different complementary dimensions, which are called 'human radicals': the human nature (the 'classic' or 'Greek' radical), both biological and psychological, which is the locus of virtue, where virtuous habits are enrooted and developed through actions; the human subjectivity or interiority (the 'modern' radical), that is the locus of self and individual freedom; and human co-existence (the 'Christian' or 'personal' radical), which underlines the person's uniqueness, the central role of relations as constitutive of the person, and the person's transcendence to her actions. In this perspective, the virtues (operative habits) perfection the natural radical (Akrivou, \& Orón, 2016), enrich the interiority of self (modern radical) and are acquired both in relation with others and for the sake of others. As it can be seen, the model of the self-of-virtue referred to Polo's Greek and modern radical, but, even if it acknowledged the relational dimension of virtue growth, it integrated it only superficially. Therefore, an expansion of this concept, integrating human co-existence and transcendence together with the self and the virtue, would be necessary.

The weaknesses of the theory of the self-of-virtue in its current state appears clearly when confronted with the principles of citizenship education, which is a relevant societal aspect of moral education. There is an ongoing academic discussion about the benefits and shortfalls of both character education and citizenship education. Both fields are "intimately connected" (Arthur, 2003, 2), but relevant differences exist regarding their conception of pluralism and the way they conceive the connection between morality and politics (Kristjánsson, 2004). Critics of citizenship education question its (supposed) downplaying of transcultural moral values, its uncritical inculcation of democratic values, a frequent political bias, and a 
lack of attention to cultural diversity (Kristjánsson, 2004, 210-211). In its turn, even if "the ultimate goal of all proper character education is to equip students with the intellectual tools to make wise choices of their own within the framework of a democratic society" (Jubilee Centre, 2017, 2), character education is criticized for being supposedly 'narrow and instrumental', emphasising the 'individual, moral dimension of character', psychologising problems 'rather than politicising them', and educating people for being 'compliant, not political' (Suissa, 2015; Kisby 2017). The theory of the selfof-virtue in its current state appears to be too individualistic and does not provide an appropriate answer to these critiques of character education.

Summarizing, it seems that there is a need of expanding the concept of self-of-virtue, in order to acknowledge the relational and societal dimension of human beings and character education. Consequently, this study addresses two research questions: how the concept of self-of-virtue can be expanded so to embrace more deeply the relational dimension of human beings and of virtue growth? What are the pedagogical implications of such conceptual expansion?

\section{Methodology}

The theory of the 'inter-processual self' (IPS) (Akrivou, \& Orón, 2016; Akrivou, Orón, Scalzo, 2018; Orón, 2015; 2016) was chosen as the starting point for expanding the concept of self-of-virtue, because it presents itself as an overarching framework for conceptualizing the self within a personalist virtue ethics epistemology in line with the assumptions of the self-ofvirtue theory: Aristotelian moral objectivism and philosophical realism. In addition, this theory stresses the processual and relational aspects of human integrity, which are precisely those missing in the theory of the self-of-virtue.

Other alternative options for expanding this concept were also considered, such as the personalism philosophy (Yepes, \& Aranguren, 2003; Altarejo, \& Naval, 2000; Marías, 1996; Merleau-Ponty, 1964; Mounier, 1936) and the theory of the 'logic of gift' (Baviera, English, 2016; Schrift, 2014). However, for the reasons mentioned above and in order to simplify the argument and saving space, these additional insights were mentioned in the discussion.

In order to answer the research question, the content of the foundational works of IPS theory mentioned above were analysed from the lens of the self-of-virtue, looking for connections between the fundamental disposition to virtue growth and the themes of 'co-existence', 'transcendence' and 'relation'. Those themes and connections were classified and synthesized in a new concept: the relational-self-of-virtue, whose features are explained in the next section. 


\section{The concept of relational-self-of-virtue}

An overview of IPS theory may be useful for understanding the features of the relational-self-of-virtue. The IPS theory claims that there are two fundamental understandings of self: "an autonomous self (AS), which is the western 'modernist' way literature understands the self and integrity...; and a contrasting inter-processual self (IPS) paradigm, which is a more processual and relational, and also an ongoing, fluid, notion of human integrity" (Akrivou, \& Orón, 2016, 223). IPS theory chooses Polo's Christian (personal) radical as starting point for moral reflection, and it presents itself as a way of integrating all the three radicals. The IPS theory proposes a model on human agency and human development based on the themes of maturation, personal agency and integration (pp. 131-144), and recognizes the role of selfhood and self-recognition (identity) in this process, which are also important components of the theory of the self-ofvirtue (Fernández González, 2019, 22-23).

The expansion of the concept of self-of-virtue is based on the assumption that the person's deep disposition to grow in virtue, which is the corner stone on which a virtuous life is built through time, is intrinsically relational. The relational dimension of virtue growth includes three aspects: receiving support from relevant others; seeking virtue growth for the sake of others; and caring actively for others' moral development. We explain them below more in detail.

Regarding the first aspect, sustainable virtue growth cannot be developed autonomously, but only together with others, in communities of virtue, given the deep relational dimension of human beings. Virtue growth is a relational human act in which relevant, caring others, are engaged. Those communities of virtue have the potentiality of enabling wider systemic virtue growth in society.

The second relational aspect refers to the motivation for virtue growth. Cultivating a relational-self-of-virtue implies a particular kind of motivation: growing in virtue for the sake of others, in order to be able to love them better and to establish more caring relations with them. It is not a self-centred growth born out of a desire for personal excellence, but an effort impelled by a transcendental motivation. Wadell (2009) formulates this idea saying that "the virtues are best understood not as acts of reason, but as strategies of love" (p. 1).

Finally, in this expanded understanding, it is not possible to develop virtue without caring for the virtue growth of those around us. It is precisely in the caring attention to others' growth than a person can develop all his/ her own potential. Virtuous leadership theory (Havard, 2007) captures well this aspect when it states that a virtuous leader is the one who develops his/her own moral virtues by seeking his/her followers' growth in virtue. 
The contribution of the inter-processual self (IPS) theory for expanding the concept of the relational-self-of-virtue has also several pedagogical implications. In the next section we will address briefly the pedagogical proposal of IPS theory as a starting point for addressing the pedagogical aspects of the development of a relational-self-of-virtue.

\section{Developing the relational-self-of-virtue: Pedagogical implications}

The pedagogical implications of IPS theory (Akrivou, Orón, Scalzo, 2018, 194-236) are particularly useful for improving the model for the development of a relational-self-of-virtue. In an IPS understanding, the whole teaching and learning process should be motivated by the common development of the learner and the teacher, in a climate of "relaxed alertness" (Caine, Caine, 2005; Salas Silva 2003), which safeguards the quality of the relationships. Youngsters' education should use largely interpersonal encounters in real life. The educational focus should be on the improvement of personal relationships, not in the mere acquisitions of knowledge or competences. Accordingly, subject-matters at school are conceived as simple 'platforms' for holistic personal growth, not as independent or even interconnected domains. The IPS proposal for assessment practices is particularly innovative: assessment should be based not in marks, but on dialogic twoway feedback, in which teacher-educator uses conversational learning and inquiry, seeking to recognize students' efforts and possibilities of relational self-development, and becomes actively involved in how the student may be able to engage better in his/her own development.

Based on these insights, the existing model for the development of a selfof-virtue (Fernández González, 2019, 19-23) needs to be expanded further for facilitating the development of a relational-self-of-virtue. Describing in detail the whole improved model is out of the scope of this paper, but directions for refining each one of its four components are outlined below.

(1) the cognitive and emotional shaping of an ideal self-of-virtue should be expanded to the shaping of an ideal relational-self-of-virtue. It may include discovering, admiring and desiring the possibility of growing in virtue together with others, being aided (inspired) by relevant (real or imaginary/virtual) others, and desiring to help those around us to grow in virtue.

(2) the commitment to virtue growth, which develops by 'following a prototype' and in personal conversations, should include, in this enlarged understanding, the relational motivation: engaging in virtue growth 'for loving others better'. This transcendental motivation flourishes most naturally in the climate of a community 
of virtue, be it the family, the school, the parish, the youth centre or a similar one.

(3) phronesis-guided involvement in virtue growth would be boosted by involvement with societal problems (helping the sick and needed, accompanying the lonely, etc.); and this care for others might not be limited to their material or intellectual needs, but should also include their moral needs: caring actively and friendly, with the due respect of personal freedom, for others' virtue growth would be a privileged way of reinforcing personal virtue growth;

(4) in this expanded understanding, virtue identity is redefined as the deep-down understanding of self as profoundly disposed (emotionally, cognitively and conatively) to relational virtue growth in the three senses explained above: growing together with others, for others' sake and through caring for others' growth. It should be noted that, in this realist framework, a 'socially situated' (Taylor, 1997) virtue identity has the persons' actual 'relational self-of virtue' as its cognitive object: virtue identity is the 'self-concept' of a person deeply disposed to grow in virtue relationally.

\section{Discussion}

In this work, based on Polo's anthropology and on 'inter-processual self' theory, the concept of the self-of-virtue was expanded into the relationalself-of-virtue. Whereas the self-of-virtue integrated Polo's classical and modern radicals, the 'relational self-of virtue' includes also the Christian personal radical: the co-existential' or relational dimension of human beings. Therefore, the refined concept of relational-self-of-virtue combines the three radicals of human beings: the Greek, the modern and the personal radical. In this discussion the resonance of this enlarged concept with some of the current anthropological theories is addressed, and some pedagogical recommendations are put forward.

The understanding of human moral development proposed by the theory of the relational-self-of-virtue is deeply connected with other philosophical approaches. Without pretending being exhaustive, we will point briefly to some of them. According to Narvaez (2014), current neurobiological studies support the assumption that, given that humans are dynamic systems highly immature at birth, the self is initially shaped through relational experiences with caregivers. This confirms the centrality of the relational dimension of moral development since early childhood. This approach is also consistent with an understanding of humans as relational beings advocated by the personalist philosophy (Mounier, 1936; Marías, 1996), which acknowledges that the roots of person's dignity dwell both in each person's singular being 
(uniqueness), which constitutes her intimacy, and in our shared humanity. The concept of a relational-self-of-virtue is also coherent with the theory of the "logic of gift" (Schrift, 2014), which inspires people both to recognize and honour the received gifts of personhood and life, and to freely choose to relate with others in a benevolent and loving way, beyond the logic of duty and obligation (Baviera, English, Guillén, 2016).

The following practical pedagogical recommendations, which include 'taught' and 'caught' approaches, can be useful for enhancing the development of youngsters' relational-self-of virtue at school and in the family:

- The 'taught' approach (explicit teaching of the emotional and cognitive contents of the relational-self-of-virtue) could be implemented in several ways, for example, explaining with the appropriate words and examples the possibility of growing in virtue together with others; analysing or playing stories of moral exemplars who could open youngsters the horizon of a life of self-giving to the service of others; illustrating with the aid of graphic design the beautifulness of personal effort for growing in virtue for others' sake; and watching and discussing movies that show characters' indirect personal improvement when caring for and serving others with a transcendent motivation.

- The personal and social benefits of developing a relational-self-ofvirtue can also be 'caught' by youngsters when they are surrounded by an atmosphere of care and respect for others. The school and the family might be framed as 'communities of virtue growth', in which moral efforts are considered to be more important than results or appropriate behaviour, and in which each person cares for the wellbeing and moral development of others, within a culture of mutual service and care for each person. Parents', teachers' and other relevant adults' example of personal effort and resilience seeking for virtue growth (for example, asking children pardon for an inappropriate attitude, or verbalizing their desire to become better persons) may have a much bigger impact than theoretical explanations to help them understand that virtue growth is a lifelong concern, and that it is normal to have failures and to bounce back.

As a conclusion, this work suggests that focussing on the development of youngsters' relational-self-of-virtue in the family and in formal education would help to avoid a fragmented virtue education. This approach would be an appropriate lens for effective moral education in the digital era. It would also contribute to harmonize character education and citizenship education. 


\section{Acknowledgements}

Project financed by the European Regional Development Fund. Postdoctoral project number 1.1.1.2/VIAA/1/16/071.

\section{References}

Akrivou, K., \& J. V. Orón. (2016). Two Kinds of Human Integrity: Towards the Ethics of the Inter-Processual Self. In: K. Akrivou \& A. J. G. Sison (Eds.), Challenges of Capitalism for Virtue Ethics and the Common Good: Interdisciplinary Perspectives (pp. 221-251). Cheltenham, U.K.: Edward Elgar.

Akrivou, K., Orón, J. V., \& Scalzo, G. (2018). The Inter-processual Self: Towards a Personalist Virtue Ethics Proposal for Human Agency. Newcastle upon Tyne: Cambridge Scholars Publishing.

Altarejo, F., \& Naval, C. (2000). Filosofía de la Educación. Navarra: EUNSA.

Arthur, J. (2003). Education with Character: The Moral Economy of Schooling. London: Routledge Falmer.

Baviera, T., English, W., \& Guillén, M. (2016). The 'Logic of Gift': Inspiring Behavior in Organizations beyond the Limits of Duty and Exchange. Business Ethics Quarterly, 26(2), 159-180. https://doi.org/10.1017/beq.2016.26

Caine, R. N., Caine, G., \& McClintic, C. L. (2005). Getting Started. In: R. N. Caine, G. Caine, \& C. L. McClintic (Eds.), 12 Brain/Mind Learning Principles in Action: The Fieldbook for Making Connections (pp. 1-18). Thousand Oaks: Corwin Press.

Carr, D. (2018). Cultivating Moral Character and Virtue in Professional Practice. Abingdon, U.K.: Routledge.

Darnell, C., Gulliford, L., Kristjánsson, K., \& Paris, P. (2019). Phronesis and the Knowledge-Action Gap in Moral Psychology and Moral Education: A New Synthesis? Human Development, 1-29. https://doi.org/10.1159/000496136

Emmons, R. A. (2009). Greatest of the Virtues? Gratitude and the Grateful Personality. In: D. Narváez, \& D. K. Lapsley, (Eds.), Personality, Identity, and Character: Explorations in Moral Psychology (pp. 256-270). Cambridge, U.K.: Cambridge University Press.

Fernández González, M. J. (2019). At the Heart of Virtue Growth: Self-of-Virtue and Virtue Identity. Estudios sobre Educación, 36, 9-29. https://doi.org/10.15581/004.36.9-29.

Harrison, T., Arthur, J., \& Burn, E. (n.d.). Character Education Evaluation Handbook for Schools. Birmingham: Jubilee centre for character and virtues, University of Birmingham. Retrieved from https://www.jubileecentre.ac.uk/1721/character-education/ teacherresources/evaluation-handbook-for-schools

Havard, A. (2007). Virtuous Leadership: An Agenda for Personal Excellence. Strongsville, OH: Scepter Publishers.

Jubilee Centre for Character and Virtues. (2017). A Framework for Character Education in Schools. Birmingham: University of Birmingham, Jubilee Centre for Character and Virtues. Retrieved from www.jubileecentre.ac.uk/userfiles/jubileecentre/pdf/ charactereducation/Framework\%20for\%20Character\%20Education.pdf

Kisby, B. (2017). Politics is Ethics Done in Public: Exploring Linkages and Disjunctions between Citizenship Education and Character Education in England. Journal of Social Science Education, 16(3), 8-21. https://doi.org/10.4119/jsse-835 
Kristjánsson, K. (2004). Beyond Democratic Justice: A Further Misgiving about Citizenship Education. Journal of Philosophy of Education, 38(2), 207-219. https://doi. org/10.1111/j.0309-8249.2004.00376.x

Kristjánsson, K. (2015). Aristotelian Character Education. London: Routledge.

Kristjánsson, K. (2016). Aristotle, Emotions, and Education. Abingdon, U.K.: Routledge.

Marías, J. (1996). Persona. Madrid: Alianza editorial.

McCabe, M. M. (2016). The Unity of Virtue: Plato's Models of Philosophy. Aristotelian Society Supplementary Volume, 90(1), 1-25. https://doi.org/10.1093/arisup/akw003

Merleau-Ponty, M. (1964). L'Oeil et l'Esprit. Paris: Gallimard.

Morgan, B., Gulliford, L., \& Kristjánsson, K. (2017). A New Approach to Measuring Moral Virtues: The Multi-Component Gratitude Measure. Personality and Individual Differences, 107, 179-189. https://doi.org/10.1016/j.paid.2016.11.044

Mounier, E. (1936). Manifeste au Service du Personnalisme. Paris: Seuil

Narvaez, D. (2014). Neurobiology and the Development of Human Morality: Evolution, Culture, and Wisdom (Norton Series on Interpersonal Neurobiology). New York, USA: WW Norton \& Company.

Orón, J. V. (2015). Leonardo Polo's Integrative Dynamic as a Philosophical Framework for Understanding Neuroscience. Journal of Polian Studies, 2, 109-36.

Orón, J. V. (2016). Nueva Propuesta de Educacion Emocional en Clave de Integracion y al Servicio del Crecimiento. Metafisica y Persona. Filosofia, Conocimiento y Vida, 16, 91-152. http://dx.doi.org/10.24310/Metyper.2016.v0i16.2684

Peters, R. S. (2015). Moral Development and Moral Education (Routledge Revivals). Abingdon, U.K.: Routledge.

Polo, L. (1999). Antropología Transcendental. Navarra: EUNSA.

Polo, L. (2007). Persona y Libertad. Navarra: EUNSA.

Polo, L., \& Corazón, R. (2005). Lo Radical y la Libertad. Cuadernos de Anuario Filosofico, 179. Pamplona: Universidad de Navarra.

Salas Silva, R. (2003). ¿La Educación Necesita Realmente la Neurociencia? Estudios Pedagógicos (Valdivia), 29, 155-71. https://doi.org/10.4067/S0718-07052003000100011

Schrift, A. D. (2014). The Logic of the Gift: Toward an Ethic of Generosity. Abingdon, U.K.: Routledge.

Suissa, J. (2015). Character Education and the Disappearance of the Political. Ethics and Education, 10(1), 105-117. https://doi.org/10.1080/17449642.2014.998030

Taylor, C. (1997). La Liberte des Modernes. Paris: Presses universitaires de France.

Wadell, P. J. (2009). The Primacy of Love: An Introduction to the Ethics of Thomas Aquinas. Oregon, USA: Wipf and Stock Publishers.

Walker, D. I., Roberts, M. P., \& Kristjánsson, K. (2015). Towards a New Era of Character Education in Theory and in Practice. Educational Review, 67(1), 79-96. https://doi.org/ 10.1080/00131911.2013.827631

Whitehead, J. D., \& Whitehead, E. E. (2015). The Virtue of Resilience. New York: Orbis Books.

Yepes, R., \& Aranguren, J. (2003). Fundamentos de Antropología. Navarra: EUNSA. 